\title{
Time of introducing component crop influences productivity of intercropping system
}

\author{
M. O. IWUAGWU*, D. A. OKPARA \& C. O. MUONEKE \\ (M.O.I.: Department of Plant Science and Biotechnology, Abia State University, P.M.B. 2000, \\ Uturu, Abia State, Nigeria; D.A.O \& C.O.M.: Department of Agronomy, Michael Okpara \\ University of Agriculture, Umudike, P.M.B. 7267, Umuahia, Abia State, Nigeria) \\ *Corresponding author's email: iroegbumary@yahoo.com
}

\begin{abstract}
Field experiment was conducted at National Horticultural Research Institute (NIHORT), Mbato Sub-station, Okigwe, Imo State, South-eastern Nigeria in the 2012 and 2013 cropping seasons to establish the most appropriate time to introduce component crops in cocoyam/cowpea mixture. Five different planting schemes (two and four weeks before, two and four weeks after and same day) and two cowpea genotypes (climbing Akidienu and erect IT97K-499-35) were used. The component crops were grown in monocultures to assess the productivity of the systems. The experimental design used was a completely randomized design with three replicates. Growth and yield of cocoyam and the cowpea genotypes increased significantly $(\mathrm{P}<0.05)$ when either of the component crops was planted earlier than the other. Intercropping reduced significantly $(P<0.05)$ cocoyam yield by $0.7-74 \%$ in IT97K-499-35 and $22-80 \%$ in Akidienu. Sowing the cowpea genotypes the same day or before cocoyam resulted in over-yielding of cowpea, whereas sowing Akidienu and IT97K-499-35 after cocoyam caused pod yield reductions of $64 \%-73 \%$ and $32 \%-59 \%$ on average, respectively. Cocoyam planted two weeks before IT97K-499-35 produced more satisfactory yields of the intercrops than the other planting schedules with LER, LEC and ATER of 2.15, 1.03 and 1.57, respectively.
\end{abstract}

Keywords: cocoyam; cowpea genotypes; intercropping; mixture productivity; planting schedule Original scientific paper. Received 18 Jun 2019; revised 29 Sep 2020

\section{Introduction}

In Nigeria, intercropping, the practice of growing two or more crops together is a popular cropping system among small-scale farmers due to scarcity of land, resulting from population explosion. It is a strategy adopted for equitable and judicious utilization of land resources and farming inputs, including labour so as to get increased total productivity per unit area (Marer et al., 2007). Intercropping helps in the control of weeds, insects, and diseases.
It increases the length of production cycles, improves seed quality and minimizes the use of inorganic nitrogen fertilizers through the use of legumes as components of intercrop mixture (Dhima et al., 2007; Zhu et al., 2010). The reduction in the use of inorganic nitrogen fertilizer will in turn reduce water pollution from runoff/leaching of nitrogen into water bodies. Several studies on intercropping have shown that intercrop may give higher and more stable yield than when any of the components

Ghana Jnl Agric. Sci. 55 (2), $10-25$

GJAS is an Open Access Journal and distributed under the terms of the Creative Commons (CC) License [CC BY 4.0] 
are grown as sole crop i.e. over-yielding, termed mutual cooperation (Adeniyan et al., 2004; Mohammadu et al., 2009; Iwuagwu et al., 2017) due to complementarity effects of the system. Thus, it provides food security, which is considered more important than food maximization in the developing world (Brintha \& Seran, 2009). A meta-analysis of intercropping in African systems conducted by Himmelstein et al. (2017) revealed that intercropping increased crop yield by $23 \%$ on average and gross income by $170 \mathrm{USD} / \mathrm{ha}$. This meta-analysis also indicated that intercropping is an advantageous sustainable agricultural practice.

Planting date among other factors including plant architecture, plant geometry, growth habit, density, spatial arrangement, and soil fertility management, affects the efficiency of resources (light, water and nutrients) used in an intercrop mixture (Singh \& Ajeigbe, 2003; Petu-Ibikumle et al., 2010), hence the productivity of the system. Research findings have suggested varied times to intercrop legumes in mixtures to ensure maximum yield of the component crops. Studies conducted by Okpara (2000) on cowpea/maize mixture showed that plant height, leaf area index, dry matter and pod yields in vegetable cowpea, as well as seed yield in maize, were significantly decreased due to delay in the introduction of either crop in the mixture, whereas best results were obtained when maize and vegetable cowpea were sown same day. Sarkodie-Addo and Abdul-Rahaman (2012) reported optimum yields when maize and soybean were sown simultaneously. On the contrary, Osang et al. (2014) suggested the sowing of maize two weeks after planting soybean as this planting schedule gave higher advantages (Land equivalent ratio) than other planting schedules. Therefore, determining the appropriate time to plant a component crop in any mixture is important in maximizing the yield of both crops.

Cocoyam is one of the staples in the south east and south south Nigeria (Azeez \& Madukwe, 2010). It is mostly cultivated by small-scale and resource-poor farmers (Onyeka, 2014) who do not bother about the complementarities of their intercrop system nor have specific dates to sow a component crop in an intercrop system. Although, the most common crop mixtures in these areas involve yam, cassava, maize, plantain and cocoyam as major food crops in all possible combinations with each other; combinations involving legumes have also been reported (Okpara, 2000; Undie et al., 2012; Ekwere et al., 2013; Mbah, 2018). Legumes are indispensable in many intercropping systems. They increase nitrogen availability due to their ability to fix atmospheric nitrogen; hence competition for soil nitrogen from legumes is less than from other crops in mixture. Also, the other crops (which are non-legumes) benefit as they obtain additional nitrogen from that released by the legumes component into the soil ( $\mathrm{Li}$ et al., 2013) through nitrogen excretion and nodule decomposition. According to Li et al. (2009), about $15 \%$ of nitrogen in an intercropped cereal is contributed by legumes.

There are no documented reports on the best time to introduce cocoyam in cocoyam/ cowpea intercrop. Therefore, this research was undertaken to ascertain the most suitable time to introduce component crops in cocoyam/ cowpea intercropping.

\section{Materials and Methods}

Study location

The experiment was carried out at the National Horticultural Research Institute (NIHORT), Mbato Sub-Station, Okigwe, Imo 
State, Nigeria. NIHORT is located at latitude $5^{\circ}$ $33^{\prime} \mathrm{N}$ and longitude $7^{\circ} 23^{\prime} \mathrm{E}$ and $139 \mathrm{~m}$ above sea level. The area is characterized as a humid rainforest zone and the soil is sandy loam. The experimental site had bushy vegetation which was ploughed and used for this experiment.

\section{Collection of materials}

The cocoyam (Colocasia esculenta var $\mathrm{NCe} 001$ ) cormels used for this study were bought from a local market in Nenwe, Augwu LGA, Enugu State, Nigeria. Two varieties of cowpea of different growth habits- climbing Akidienu and erect IT97K-499-35 were used. The climbing Akidienu was bought from a local market in Umulolo, Okigwe, Nigeria while the erect IT97K-499-35 was obtained from International Institute for Tropical Agriculture (IITA), Ibadan.

\section{Field preparation and soil sampling}

In each year, the site was doubleploughed and ridged with a tractor. The experimental area was marked into three blocks which represent the replicates and each block was divided into thirteen experimental plots. Each plot measured $4 \mathrm{~m} \times 3 \mathrm{~m}\left(12 \mathrm{~m}^{2}\right)$ with a central yield area of $2 \mathrm{~m} \times 2 \mathrm{~m}$. Each plot was properly labeled based on the treatment assigned to it for proper data collection.

Soil samples were collected with a soil auger to a depth of $20 \mathrm{~cm}$ from different locations of the site and bulked into composite sample. The composite soil sample was airdried, passed through a $2 \mathrm{~mm}$ sieve and then analyzed for its Physico-chemical properties in the soil laboratory unit of National Root Crops Research Institute, Umudike, Abia State, Nigeria. Nitrogen, potassium and organic matter contents of the soil were low with values between $0.04 \%$ and $0.05 \%, 0.074 \mathrm{cmol}$

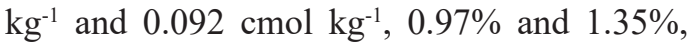

respectively in the two years of cropping. The soil was sandy loam and slightly acidic having pH of 4.2 and 5.3 in 2012 and 2013, respectively (Table 1).

Experimental design, treatment and treatment allocation

The experiment was laid out in a randomized complete block design with three replicates. The treatments comprised five different times of introducing cocoyam into the mixture, which is as follows: cocoyam planted four weeks before cowpea, two weeks before cowpea, same day with cowpea, two weeks after cowpea and four weeks after cowpea. The sole crops were included as treatments so as to assess the productivity of the intercrop system. A total of thirteen treatments were used for the study. The treatments were assigned randomly to the plots.

\section{Planting}

The cocoyam and cowpea genotypes were planted based on the planting schedules stated above. The cocoyam cormels were planted on ridges at a depth of $15 \mathrm{~cm}$. One cormel was planted per hole at a planting distance of $1 \mathrm{~m} \times 1 \mathrm{~m}$. There were twelve plants per plot resulting in a total of about 10,000 plants per hectare. The cowpea varieties were sown three seeds per hole at a depth of $3 \mathrm{~cm}$ and a planting distance of $1 \mathrm{~m} \times 0.25 \mathrm{~m}$ in between the cocoyam corms. The resulting seedlings were thinned down to one per hole at two weeks after planting (WAP) resulting in a total of 40,000 plants per hectare. The same planting depths and distances were used for the sole crops.

\section{Maintenance of experimental plots}

Filling of gaps was done at one MAP. Weeding was done manually. The cowpea 
seedlings were protected from insect attack by spraying with Deltamethrine 12.5 EC from two WAP. Also, the blanket application of NPK (15:15:15) fertilizer was applied to all the cocoyam stands in all the experimental plots at the rate of $120 \mathrm{~kg} \mathrm{ha}^{-1}$ at three WAP using band placement method.

\section{Data collection on the cocoyam}

Growth and yield data collected for the cocoyam include plant height, number of leaves, leaf area index (LAI), number of corms per plant, corm weight (g/corm) and corm yield $\left(\mathrm{t} \mathrm{ha} \mathrm{a}^{-1}\right)$. The leaf area index (LAI) was determined by first determining the leaf area using the formula of Biradar et al. (1978) as: Leaf Area $=0.917(\mathrm{LW})$.

Where $\mathrm{L}$ and $\mathrm{W}$ are the length and width of the cocoyam leaf respectively.

Leaf area index was calculated by dividing the total leaf area by the area occupied by the plant (Biradar et al., 1978).

At physiological maturity, the cocoyam plants from the net plots were harvested, the number of corms/cormels were physically counted and recorded. The corms/cormels were weighed to obtain the corms weight and thereafter the weights were converted to tons per hectare to obtain the corms yield.

\section{Data collection on the cowpea}

Data collected for the cowpea were the plant height, root and shoot dry weights, number of pods per plant, pod weight, pod yield, number of seeds per pod, 100 seed weight and seed yield.

Five cowpea plants of each variety were randomly selected from each plot. Height of the selected cowpea plants were measured at one MAP from the base of the stem at soil level to the terminal bud of the main stem with the aid of a measuring tape. The mean was calculated and recorded accordingly.

The root and shoot dry weights of the cowpea varieties were determined at one MAP using the same plants used for the height measurements. The plants were carefully uprooted, washed and separated into roots and shoots, cut into pieces, placed into properly labeled envelopes and dried in an electric oven at a temperature of $65^{\circ} \mathrm{C}$ until a constant weight was achieved. The samples were allowed to cool and thereafter weighed and their weights were recorded. In the case of yield measurements, ten plants were selected from the net plot and tagged. Fresh green pods of the cowpea varieties were harvested from these plants weekly as the pods mature from two MAP. The number of pods was counted and the average recorded. At each harvest, the fresh green pods were weighed with an electronic balance and the mean weights recorded. The weight of pods was converted to tons per hectare to obtain the pod yield.

The number of seeds per pod was determined by randomly selecting ten pods from each plot. The selected pods were split longitudinally into two and the seeds in each pod counted and the average number of seeds obtained was recorded. 100 seeds weight was determined by shelling harvested dry pods from each plot. The shelled seeds were sundried and mixed properly after which 100 seeds were randomly selected from the seed lot, weighed using an electronic balance and the mean weights recorded.

\section{Assessment of intercrop productivity}

\section{i. Land equivalent ratio (LER)}

The LER was calculated from the yield data using the formula of Trenbath (1974) as shown in the equation below: 
$\mathrm{LER}=\mathrm{ab} / \mathrm{a}+\mathrm{ba} / \mathrm{b}$

Where $\mathrm{a}=$ sole crop yield of cocoyam; $\mathrm{ab}=$ intercrop yield of cocoyam; $b=$ sole crop yield of cowpea; ba = intercrop yield of cowpea

\section{ii. Land equivalent coefficient (LEC)}

This was calculated as the product of LERs of the intercrop component as proposed by Adetiloye and Ezedinma (1983). Thus:

$\mathrm{LEC}=\mathrm{ab} / \mathrm{a} \times \mathrm{ba} / \mathrm{b}$

\section{iii. Area $x$ time equivalent ratio (ATER)}

This was calculated using the formula of Hiebsch and McCollum (1987) as:

$\mathrm{ATER}=[(\mathrm{RYa} \times \mathrm{Da})+(\mathrm{RYb} \times \mathrm{Db})] / \mathrm{D}$

Where: $\mathrm{RYa}=$ cocoyam relative yield; $\mathrm{Da}=$ cocoyam duration; $\mathrm{RYb}=$ cowpea relative yield; $\mathrm{Db}=$ cowpea duration; $\mathrm{D}=$ duration of the whole intercrop

\section{Data analyses}

Data collected were subjected to analysis of variance using Genstat Discovery Edition 3 Package of 2007 and significant means were separated and compared using Fisher's Least Significant Difference (F-LSD) at $5 \%$ probability level.

\section{Results}

Cocoyam crop growth characteristics, yield and yield attributes

The effect of time of introducing component crops in cocoyam/cowpea intercrop on plant height of cocoyam was only significant $(\mathrm{P}<0.05)$ at five MAP in both years (Table 2). Planting cocoyam two weeks before and the same day with climbing Akidienu genotype resulted in significantly $(\mathrm{P}<0.05)$ taller plants than planting cocoyam four weeks after Akidienu in both years. Similarly, in 2012, planting cocoyam before, same day and two weeks after the erect IT97K-499-35 produced comparable plant heights, that was significantly higher than that of four weeks after. However, in 2013, cocoyam planted two weeks before erect IT97K-499-35 genotype was significantly taller than that of the sole crop and also than that planted two or four weeks after the erect IT97K-499-35.

Significant effects of time of introducing cocoyam on the number of leaves were found at three and five MAP in 2012 and all the sampling dates in 2013 (Table 3). A significantly higher number of leaves was recorded when cocoyam was planted before than after any of the cowpea genotypes in 2012. However, in 2013, the number of leaves produced by cocoyam when intercropped with climbing Akidienu irrespective of the planting scheme was statistically similar except at one MAP where cocoyam planted four weeks before the climbing Akidienu produced significantly higher number of leaves than when it was planted four weeks after. On the contrary, cocoyam planted two or four weeks before the erect IT97K-499-35 genotype produced number of leaves that were significantly higher than that of the later planted cocoyam. Furthermore, in both years of cropping, the number of leaves of cocoyam produced under intercropping with climbing Akidienu was generally lower compared to intercropping with erect IT97K-499-35 and also to the sole cocoyam.

The effect of time of introducing cocoyam on the Leaf area index (LAI) of cocoyam was significant at all sampling months in 2012 and three and five MAP in 2013 (Table 4). In both years of cropping, LAI of cocoyam was significantly $(\mathrm{P}<0.05)$ higher when cocoyam was planted before than after any of the cowpea genotypes except at one 
MAP in 2012 where cocoyam planted with the erect no matter the time it was introduced produced comparable LAI values. Also, at five MAP, cocoyam planted two weeks before the erect IT97K-499-35 produced significantly the highest LAI. However, intercropping with Akidienu significantly reduced LAI of cocoyam in 2012 but significantly increased it when intercropped with erect IT97K-499-35 in 2013. Planting cocoyam before any of the cowpea genotypes produced significantly higher number of corms and corm yield than planting after the cowpea genotypes in both years (Table 5). On average, corm yield produced when cocoyam was planted two or four weeks before the erect IT97K-499-35 was similar to that of the sole cocoyam but significantly higher than the yields obtained when the mixture was planted the same day or when cocoyam was planted after cowpea regardless of the growth habit. Across the genotypes and years, corm yields produced when cocoyam was planted two and four weeks before cowpea were similar $\left(3.5 \mathrm{t} \mathrm{ha}^{-1}\right)$ but higher than the yields obtained when cocoyam was planted the same day, two and four weeks after cowpea by $52 \%$, $230 \%$ and $210 \%$, respectively.

Cowpea growth characteristics, yield and yield attributes

The effect of time of introducing cowpea on cowpea plant height in cocoyam/cowpea intercrop was significant in 2013 only (Table 6). Sowing climbing Akidienu two weeks before and two weeks after cocoyam gave comparable plant height values that were significantly higher than sowing four weeks after cocoyam. Also, plant heights of climbing Akidienu sown two weeks before and two weeks after cocoyam were significantly higher than the plant heights of the erect IT97K-499-35 cowpea at all the planting schedules including the sole crop. Notwithstanding the planting schedules, intercropping had no remarkable effect on the plant height of the erect IT97K-499-35. Root and shoot dry matter production of the cowpea genotypes were not significantly affected by time of introduction of cowpea in the mixture in both years.

On average, sowing of the cowpea genotypes after cocoyam produced significantly lower number of pods per plant, pod weight and pod yields compared to other sowing times (Table 7). Across the two cropping seasons, pod yields produced when climbing Akidienu genotype was planted two weeks before cocoyam was at par with those of four weeks before and same day with cocoyam but higher than the pod yields produced when introduced two and four weeks after cocoyam by $223.8 \%$ and $338.3 \%$, respectively. Similarly, pod yields obtained when the erect IT97K-499-35 was sown two and four weeks before cocoyam was comparable with that of the same day planting but significantly higher than those planted two weeks after cocoyam by $111.8 \%$ and $89.6 \%$, respectively and also four weeks after cocoyam by $226.6 \%$ and $216.2 \%$, respectively. Generally, pod yields were significantly higher in erect IT97K-499-35 than in climbing Akidienu intercrop in 2013. Erect IT97K-499-35 sown two weeks before or the same day with cocoyam produced significantly higher pod yield than the cowpea sole crop on the average.

A significantly higher number of seeds were obtained when Akidienu was sown on the same day as cocoyam compared to when it was sown after cocoyam in 2012 (Table 8). Contrary to this, a comparable number of seeds were obtained in IT97K-499-35 irrespective of the planting dates and the sole crop. With 
the exception of sowing IT97K-499-35 two weeks before cocoyam in 2013, sowing the cowpea genotypes before and the same day with cocoyam resulted in a significantly higher number of seeds in relation to sowing them at four weeks after cocoyam. The number of seeds produced by Akidienu at all the planting dates was significantly higher than those of the erect IT97K-499-35 irrespective of the planting time.

In both years, statistically, similar 100 seed weight values were obtained in Akidienu regardless of the planting scheme; whereas erect IT97K-499-35 sown four weeks before cocoyam had a significantly higher 100 seed weight value than when it was sown two weeks before, in both years and same day with cocoyam in 2013 (Table 8). Generally, sowing Akidienu and IT97K-499-35 before or same day with cocoyam produced significantly higher cowpea seed yields in 2012 and 2013, respectively than sowing cowpea after cocoyam (Table 8). Moreover, seed yields of the erect IT97K-499-35 were significantly higher than those of climbing Akidienu at all planting schemes in 2013.

Total LER were on the average above 1.0 and greater when cocoyam was intercropped with erect IT97K-499-35 than with climbing Akidienu at all planting schedules (Table 9). There were yield advantages of growing the crops in the mixture as depicted by mean LERs of $1.18-2.09$ for cocoyam intercropped with climbing Akidienu and $1.53-2.15$ for cocoyam combined with erect IT97K-499-35. The partial LER showed that there was over-yielding by cowpea which contributed more to the total yield when cocoyam was planted the same day with or after the cowpea genotypes in both years and two weeks before the erect IT97K-499-35 in 2012. On the whole, the highest LER (2.15) was obtained when cocoyam was planted two weeks before the erect IT97K-499-35. LEC values were generally higher in 2012 than in 2013 cropping season and were also higher in mixtures involving cocoyam and the erect IT97K-499-35 genotype compared to that of the cocoyam and climbing Akidienu (Table 10). Mean LEC value ranged from 0.26 to 1.03 with the highest recorded when cocoyam was planted two weeks before the erect IT97K-499-35 genotype. Mean ATER were greater than unity in all mixtures involving cocoyam and the erect IT97K-499-35 genotype (regardless of the planting date) and that involving cocoyam planted the same day with climbing Akidienu (Table 10). Like the LEC, maximum ATER value was obtained when cocoyam was planted two weeks before the erect IT97K-499-35 genotype

\section{Discussion}

The results of the present investigation showed that when either cocoyam or any of the cowpea genotypes was planted at different times in the mixture, the earlier planted crop suppressed the growth and yield of the later planted crop. The earlier planted component had an initial competitive advantage over the later one as reported by Okpara (2000) and Ekwere et al. (2013). Eagles (1992) reported that early root growth was a major factor determining competitive ability with faster-growing species, exploiting nutrients in successive horizons of the soil much earlier than slow or later growing species. The difference in the efficiency of the root system may later lead to reduced growth of the shoot of the slower growing component and ultimately shading of leaves by those of the aggressive component (Eagles, 1992).

On average, planting cocoyam two weeks before the erect IT97K-499-35 produced similar corm yield with the sole cocoyam but 
higher yields than the other planting schedules, except when cocoyam was planted four weeks before the cowpea genotypes. According to IITA (1989), when there is a weak competitor in a mixture, it is advisable to enhance its performance by sowing it early, relative to the aggressor. Cocoyam has a fibrous root system, it is shallow-rooted and shows a slow growth rate, compared to cowpea. Hence it may be a weak competitor when grown in a mixture with cowpea. Corm yields were generally lower when cocoyam was combined with the climbing Akidienu cowpea in comparison with the erect IT97K-499-35 cowpea due probably to the entangling effect of the Akidienu genotype, a climber, on the cocoyam. A similar result of lower corm yield in mixture involving cocoyam/climbing Akidienu was reported by Iwuagwu et al. (2017). However, compared to the erect IT97K-499-35, the entangling effect of the climbing Akidienu hampered leaf development as well as leaf production in cocoyam hence the observed decrease in the number of leaves produced and LAI of cocoyam intercropped with climbing Akidienu. Since LAI determines the capacity of the plant to trap energy for photosynthesis (Detpiratmongkol et al., 2014), the reduced LAI following poor leaf development resulted in the reduction of photosynthetic activity and poor bulking of the cormels.

Across the years, corm yield reductions following intercropping of cocoyam with cowpea were $1 \%-74 \%$ for the erect IT97K-499-35 and $22-80 \%$ for the climbing Akidienu. On the contrary, fresh pod yields were similar when the erect IT97K-499-35 was sown the same day as, two or four weeks before cocoyam and there was over-yielding at these planting schedules compared to cowpea sole crops, regardless of growth habits.
Intercropping systems greatly contribute to crop productivity because of the effective use of resources in comparison with the monocropping system (Inal et al., 2007). This is achievable when the component crops are compatible. In all, cocoyam had a more adverse effect on the climbing Akidienu and vice versa at all planting schedules while pod yield reductions in the erect IT97K-499-35 intercrop occurred only when it was introduced after cocoyam. These results indicate that cocoyam and climbing Akidienu are not compatible components in the mixture. According to PetuIbikunle et al. (2010) compatibility of the crops should be given attention when selecting crops for intercropping.

The most common goal of intercropping is to produce a greater yield on a given piece of land by making use of resources that would otherwise not be utilized by a single crop (Ouma \& Jeruto, 2010). According to Mas-ud et al. (2016), the land equivalent ratio (LER) gives an accurate assessment of the greater efficiency of the intercropping situation. The total LERs for all the treatments were above unity, indicating that intercropping cocoyam with cowpea was beneficial. It also indicates crop complementarities (Mas-ud et al., 2016). Ekwere et al. (2013) also reported LER greater than unity in all intercropping situations (except when melon was sown four or six weeks before or after maize). Similarly, Olasantan and Babalola (2007) reported LER greater than one in cassava/melon and maize/ melon intercrops irrespective of the sowing date of melon. The highest LER productivity estimates were obtained in mixtures involving cocoyam planted two weeks before (Mean $\mathrm{LER}=2.15$, mean corm yield $=4.1 \mathrm{t} /$ ha. Mean pod yield $\left.=6.3 \mathrm{t} \mathrm{ha}^{-1}\right)$ and same day with erect IT97K-499-35 (mean LER = 2.14, mean corm 
yield $=2.35 \mathrm{t} \mathrm{ha}^{-1}$, mean pod yield $=13.45 \mathrm{t}$ $\left.\mathrm{ha}^{-1}\right)$. This shows greater complementarity effect at this planting scheme resulting in judicious utilization of land resources. Osang et al. (2014) found that sowing maize two weeks after planting soybean gave higher LER values than other planting schedules. Although planting cocoyam two weeks after the erect IT97K-499-35 also gave high mean LER of 2.10 and mean pod yield of $13.28 \mathrm{t} \mathrm{ha}^{-1}$, corm yield was poor at $1.07 \mathrm{tha}^{-1}$.

LEC values were all greater than 0.25 irrespective of the crop combination and planting date when averaged over the two years of cropping. This also indicates yield advantage (Adetiloye and Ezedinma, 1983; Wortman et al., 2012). ATER values obtained when cocoyam was planted two weeks before, two and four weeks after Akidienu were less than unity, an indication of yield disadvantage while the rest of the combinations including those involving cocoyam intercropped with IT97K-499-35 regardless of the sowing date were all greater than one. It is obvious from this result that LER tends to over-estimate land use advantage when long season growing crops are involved as earlier reported by Fukai (1993). However, LEC (1.03) and ATER (1.57) were highest when cocoyam was planted two weeks before the erect IT97K-499-35 genotype. This confirms the earlier statement that this genotype and the planting date showed greater complementarity than the other planting schemes and combinations.

\section{Conclusion and Recommendation}

From an overall consideration of the yield values, it is concluded that planting cocoyam two weeks before the erect IT97k-499-35, followed by simultaneous planting not only produced complementarities and highest average total LERs (2.15 and 2.14), ATERs (1.57 and 1.27) and LECs (1.03 and 0.94) but also produced more satisfactory yields of the intercrops than the other planting schedules, which greatly reduced the yields of either the cocoyam or cowpea. Therefore, for satisfactory yields of the component crops, planting cocoyam two weeks before the erect cowpea genotype, IT97k-499-35 or simultaneous planting of cocoyam and the erect cowpea is recommended.

\section{REFERENCES}

Adetiloye, P.O. \& Ezedinma, F.O.C. (1983) A land equivalent co-efficient (LEC) concept for the evaluation of competitive and productive interaction in simple to complex crop mixture. Ecological Modeling 19, 27 - 39.

Adeniyan O.N., Agbaje, G.O. \& Ayoola, O.T. (2004) The performance of cowpea varieties intercropped and cassava. Institute of Agricultural Research and Training Annual in house Review. Wednesday 4 Thursday 5 February, 2004.

Azeez, A.A. \& Madukwe, O.M. (2010) Cocoyam production and economic status of farming households in Abia State, South-East, Nigeria. Journal of Agriculture and Social Sciences $\mathbf{6}$, $83-86$.

Biradar, R.S., Venkateswarali, T. \& Hrishi, N. (1978) Leaf area estimation in Colocasia. Journal of Root Crops 4, 51 - 53.

Brintha, I. \& Seran, T.H. (2009). Effect of paired row planting of raddish (Raphanus sativus L.) intercropped with vegetable amaranthus (Amaranthus tricolor L.) on yield components of radish in sandy regosol. Journal of Agricultural Science 4,19-28.

Detpiratmongkol, S., Ubolkerd, T. \& Yoosukyingstaporn, S. (2014). Effects of chicken, pig and cow manures on growth and 
yield of kalmegh (Andrographis paniculata Nees). Journal of Agricultural Technology 10 (2), $475-482$.

Dhima, K.V., Lithourgidis, A.S., Vasilakoglou, I.B. \& Dordas, C.A. (2007). Competition indices of common vetch and cereal intercrops in two seeding ratio. Field Crop Research 100 (2-3), $249-256$.

Eagles, C.F. (1992). Competition for light and nutrients between natural populations of Dactylis glomerata. Journal of Applied Ecology 9, 141 $-151$.

Ekwere, O.J., Muoneke, C.O., Eka, M.J. \& Osodeke, V.E. (2013). Influence of relative sowing time on the performance and yield of maize and egusi melon intercrop. International Journal of Innovative Agriculture and Biology Research 1(2), 39 - 50.

Fukai, S. (1993). Intercropping - bases of productivity. Field Crops Research 34, 239 - 245.

Hiebsch, C.K. \& McCollum, A. (1987). Area x time equivalent ratio - a method for evaluating productivity of intercrops. Agronomy Journal 79, $15-20$.

Himmelstein, J., Ares, A., Gallagher, D. \& Myers, J. (2017) A meta-analysis of intercropping in Africa: impacts on crop yield, farmer income, and integrated pest management effects. International Journal of Agricultural Sustainability 15 (1), 1 - 10.

\section{IITA (1989). Crop Establishment Manual.} Ibadan, Nigeria.

Inal, A., Gunes, A., Zhang, F. \& Cakmak, I. (2007) Peanut/maize intercropping induced changes in rhizosphere and nutrient concentration in shoots. Plant Physiology and Biochemistry 45 (5), $350-356$.
Iwuagwu, M.O., Okpara, D.A. \& Muoneke, C.O. (2017) Varietal effect of cowpea and cow dung application rates on the productivity of cocoyam/cowpea intercrop. Journal of Experimental Agriculture International 16 (5), $1-14$.

Li, Y.F., Ran, W., Zhang, R.P., Sun, S.B. \& Xu, G.H. (2009) Facilitated legume nodulation, phosphate uptake and nitrogen transfer by arbuscular inoculation in an upland rice and mung bean intercropping system. Plant and Soil 315, 285 - 296.

Li, L., Zhang, L.Z. \& Zhang, F.Z. (2013) Crop mixtures and the mechanisms of overyielding. In: Levin, S.A. (ed.). Encyclopedia of biodiversity, $2^{\text {nd }}$ edn, vol, 2. Academic Press, Waltham, MA, USA. $82-395$.

Marer, S.B., Lingaraju, B.S. \& Shadhidhara, G.B. (2007) Productivity and economics of maize and pigeon pea intercropping under rainfed condition in northern transitional zone of Karnataka. Karnakata Journal of Agricultural Science 20 (1), 1 - 3.

Mas-ud, M., Kaba, J.S., Ofori, K. \& Salifu, G. (2016) Relative planting dates effect on the agronomic performance of maize (Zea mays L.) and groundnut (Arachis hypogeal L.) in an intercrop system. American Scientific Research Journal for Engineering, Technology, and Sciences 16, 262 - 276.

Mbah, E.U. (2018) Sequential cropping effects of vegetable cowpea on cassava in cassavacowpea intercrop, Umudike, Southern Nigeria. Journal of Agronomy 17, 123 - 135.

Mohammadu, B.J., Human, W.S., Tabi, J., Ramlan, M.F., Amartalingam, R., Sung, C.T.B. \& Ahmed, O.H. (2009) A simulation model estimates of the intercropping advantage of an immature-rubber, banana and pineapple system. American Journal of Agriculture and Biological Science 4 (3), 249 - 254. 
Okpara, D.A. (2000) Effect of time of introduction of component crops and fertilizer $-\mathrm{N}$ application on maize and vegetable cowpea grown in mixtures under the humid tropical conditions. Journal of Tropical Agriculture, Food, Environment and Extension 2, 65 - 73.

Olasantan, F.O. \& Babalola, O.A. (2007) Effects of intercropping and melon sowing date on crop growth, soil micro-environment and rhizosphere fungi and bacteria populations of maize and cassava. Biological Agriculture and Horticulture 24 (4), 415 - 436.

Onyeka, J. (2014) Status of cocoyam (Colocasia esculenta and Xanthosoma spp) in west and central Africa: production, household importance and the threat from leaf blight. Lima (Peru). CGIAR Research Program on Roots, Tubers and Bananas (RTB). Available at: www.rtb.cgiar.org

Osang, P.O., Richard, B.I. \& Iheadindueme, C.A. (2014) Influence of date of planting and time of introduction of maize on the agronomic performance of soybean-maize intercrop in Nigerian Southern-Guinea Savanna. Journal of Biology, Agriculture and Healthcare 4 (3), $136-143$.

Ouma, G.\& Jeruto,P.(2010). Sustainable horticultural crop production through intercropping: the case of fruit and vegetable crops: A review. Agriculture and Biology Journal of North America 1 (5), 1098 - 1105.

Petu-Ibikunle, A.M., Tenebe, V.A., Garba, A.A. \& Fagam, A.S. (2010). Effect of nitrogen, spatial arrangement and weeding regime on photosynthetic efficiency of cowpea in an intercrop/mixed culture with sorghum. International Journal of Agriculture 2 (2), 117 -125 .

Sarkodie-Addo, J. \& Abudul-Rahaman, L. (2012) Spatial arrangements and time of introducing an intercrop on the productivity of component crops in maize (Zea mays L.) - soybean (Glycine $\max$ (L.) Merill) intercropping systems. International Journal of Science and Advanced Technology 2 (11), 103 - 108.

Singh, B.B. \& Ajeigbe, H.A. (2003) Improving cowpea cereal based on cropping system in the dry savannah of West Africa. Journal of Agronomy and Crop Science 189 (3), 278 286.

Trenbath, B.R. (1974) Application of growth model to problems of the productivity and stability of mixed stands. In: Proceedings of the $12^{\text {th }}$ International Grass Land Congress, Moscow. $546-558$.

Undie, U.L., Uwah, D.F. \& Attoe, E.E. (2012) Effect of intercropping and crop arrangement on yield and crop productivity of late season maize/soybean mixtures in the humid environment of south south Nigeria. Journal of Agricultural Science 4 (4), 37 - 50.

Wortman, S.E., Francis, C.A., Bernards, M., Drijber, R. \& Lindquist, J.L. (2012) Optimizing cover crop benefits with diverse mixtures and an alternative termination method. Agronomy Journal 104, 1424 - 1135.

Zhu, J., Zhang, C. \& Lynch, J.P. (2010) The utility of phenotypic plasticity for root hair length for phosphorus acquisition. Functional Plant Biology 37 (4), 313 - 322. 
Time of introducing component crop influences...

TABLE 1

Some physicochemical properties of the experimental soil in 2012 and 2013 cropping seasons

\begin{tabular}{|c|c|c|}
\hline Property & 2012 & 2013 \\
\hline \multicolumn{3}{|c|}{ Physical Properties } \\
\hline Sand (\%) & 67.80 & 71.80 \\
\hline Clay (\%) & 14.40 & 11.40 \\
\hline Silt (\%) & 17.80 & 16.80 \\
\hline Textural class & Sandy loam & Sandy loam \\
\hline \multicolumn{3}{|c|}{ Chemical Properties } \\
\hline $\mathrm{pH}\left(\right.$ in $\left.\mathrm{H}_{2} \mathrm{O}\right)$ & 4.2 & 5.3 \\
\hline $\mathrm{P}(\mathrm{mg} / \mathrm{kg})$ & 43.50 & 47.80 \\
\hline $\mathrm{N}(\%)$ & 0.04 & 0.05 \\
\hline OM (\%) & 0.97 & 1.35 \\
\hline $\mathrm{K}(\mathrm{cmol} / \mathrm{kg})$ & 0.074 & 0.092 \\
\hline
\end{tabular}

TABLE 2

Effect of time of introducing cocoyam on plant height $(\mathrm{cm})$ of cocoyam at different sampling dates in 2012 and 2013 cropping seasons

\begin{tabular}{|c|c|c|c|c|c|c|}
\hline \multirow{3}{*}{ Time of introducing cocoyam } & & \multicolumn{5}{|c|}{ Months after planting } \\
\hline & 1 & 3 & 5 & 1 & 3 & 5 \\
\hline & & 2012 & & & 2013 & \\
\hline 4 weeks before $A$ kidienu & 13.3 & 33.6 & 45.6 & 10.4 & 34.8 & 36.9 \\
\hline 2 weeks before Akidienu & 15.3 & 38.9 & 51.0 & 12.3 & 37.6 & 43.4 \\
\hline Same day as Akidienu & 15.7 & 39.2 & 53.2 & 13.5 & 41.1 & 42.7 \\
\hline 2 weeks after Akidienu & 12.6 & 35.4 & 42.6 & 14.0 & 29.3 & 33.0 \\
\hline 4 weeks after Akidienu & 13.6 & 28.4 & 36.3 & 17.1 & 26.1 & 29.4 \\
\hline 4 weeks before IT97K-499-35 & 13.4 & 34.9 & 47.1 & 12.0 & 38.1 & 44.6 \\
\hline 2 weeks before IT97K-499-35 & 14.7 & 35.5 & 47.1 & 11.9 & 40.8 & 47.9 \\
\hline Same day as IT97K-499-35 & 14.4 & 37.4 & 51.0 & 11.7 & 37.6 & 43.5 \\
\hline 2 weeks after IT97K-499-35 & 14.5 & 31.4 & 41.4 & 12.5 & 28.3 & 34.1 \\
\hline 4 weeks after IT97K-499-35 & 12.4 & 27.7 & 33.4 & 14.5 & 30.8 & 32.8 \\
\hline Sole cocoyam & 12.1 & 31.3 & 45.1 & 11.3 & 32.1 & 35.0 \\
\hline LSD 0.05 & NS & NS & 10.3 & NS & NS & 12.0 \\
\hline
\end{tabular}

$\mathrm{NS}=$ not significant 
TABLE 3

Effect of time of introducing cocoyam on number of leaves per cocoyam plant at different sampling dates in 2012 and 2013 cropping seasons

\begin{tabular}{|c|c|c|c|c|c|c|}
\hline \multirow{3}{*}{ Time of introducing cocoyam } & \multicolumn{6}{|c|}{ Months after planting } \\
\hline & 1 & 3 & 5 & 1 & 3 & 5 \\
\hline & \multicolumn{3}{|c|}{2012} & \multicolumn{3}{|c|}{2013} \\
\hline 4 weeks before Akidienu & 3.9 & 13.5 & 13.9 & 6.8 & 14.8 & 14.9 \\
\hline 2 weeks before Akidienu & 4.4 & 10.8 & 12.2 & 5.7 & 10.0 & 11.9 \\
\hline Same day as Akidienu & 4.4 & 6.1 & 8.8 & 6.8 & 8.7 & 10.2 \\
\hline 2 weeks after Akidienu & 3.9 & 5.2 & 6.3 & 3.1 & 7.2 & 7.8 \\
\hline 4 weeks after Akidienu & 3.9 & 5.4 & 7.2 & 3.7 & 6.4 & 10.9 \\
\hline 4 weeks before IT97K-499-35 & 3.9 & 17.3 & 19.5 & 8.4 & 19.2 & 23.6 \\
\hline 2 weeks before IT97K-499-35 & 4.3 & 11.9 & 17.8 & 8.4 & 14.7 & 34.6 \\
\hline Same day as IT97K-499-35 & 4.1 & 8.4 & 11.4 & 9.3 & 12.5 & 16.6 \\
\hline 2 weeks after IT97K-499-35 & 4.2 & 5.2 & 6.5 & 4.0 & 7.6 & 8.9 \\
\hline 4 weeks after IT97K-499-35 & 3.9 & 5.3 & 6.9 & 3.9 & 6.8 & 7.8 \\
\hline Sole cocoyam & 3.7 & 20.3 & 22.0 & 8.0 & 17.4 & 20.6 \\
\hline LSD 0.05 & NS & 3.9 & 5.0 & 3.2 & 9.1 & 8.9 \\
\hline
\end{tabular}

$\mathrm{NS}=$ not significant

TABLE 4

Effect of time of introducing cocoyam on LAI of cocoyam at different sampling dates in 2012 and 2013 cropping seasons

\begin{tabular}{|c|c|c|c|c|c|c|}
\hline \multirow{3}{*}{ Time of introducing cocoyam } & \multicolumn{4}{|c|}{ Months after planting } & \multirow[b]{2}{*}{3} & \multirow{3}{*}{5} \\
\hline & 1 & 3 & 5 & 1 & & \\
\hline & \multicolumn{3}{|c|}{2012} & \multicolumn{2}{|r|}{2013} & \\
\hline 4 weeks before Akidienu & 0.06 & 0.55 & 0.59 & 0.06 & 0.45 & 0.47 \\
\hline 2 weeks before Akidienu & 0.09 & 0.50 & 0.55 & 0.09 & 0.31 & 0.44 \\
\hline Same day as Akidienu & 0.08 & 0.28 & 0.31 & 0.06 & 0.28 & 0.42 \\
\hline 2 weeks after Akidienu & 0.03 & 0.19 & 0.21 & 0.02 & 0.13 & 0.17 \\
\hline 4 weeks after Akidienu & 0.03 & 0.14 & 0.16 & 0.03 & 0.10 & 0.12 \\
\hline 4 weeks before IT97K-499-35 & 0.06 & 0.76 & 0.85 & 0.06 & 0.53 & 0.71 \\
\hline 2 weeks before IT97K-499-35 & 0.07 & 0.56 & 0.79 & 0.08 & 0.83 & 1.01 \\
\hline Same day as IT97K-499-35 & 0.07 & 0.38 & 0.46 & 0.09 & 0.36 & 0.54 \\
\hline 2 weeks after IT97K-499-35 & 0.04 & 0.15 & 0.18 & 0.03 & 0.13 & 0.19 \\
\hline 4 weeks after IT97K-499-35 & 0.03 & 0.10 & 0.13 & 0.06 & 0.11 & 0.16 \\
\hline Sole cocoyam & 0.05 & 0.82 & 0.90 & 0.08 & 0.43 & 0.52 \\
\hline LSD 0.05 & 0.04 & 0.25 & 0.28 & NS & 0.23 & 0.38 \\
\hline
\end{tabular}

$\mathrm{NS}=$ not significant 
Time of introducing component crop influences...

TABLE 5

Effect of time of introducing cocoyam on yield and yield components of cocoyam in 2012 and 2013 cropping seasons

\begin{tabular}{|c|c|c|c|c|c|c|c|}
\hline \multirow[b]{2}{*}{ Time of introducing coco } & \multicolumn{2}{|c|}{ NC per plant } & \multicolumn{2}{|c|}{ WC g/corm } & \multicolumn{3}{|c|}{$C Y t h a^{-1}$} \\
\hline & 2012 & 2013 & 2012 & 2013 & 2012 & 2013 & Mean \\
\hline 4 weeks before Akidienu & 11.2 & 10.7 & 35.6 & 25.5 & 3.9 & 2.55 & 3.24 \\
\hline 2 weeks before Akidienu & 8.6 & 9.3 & 37.2 & 26.2 & 3.21 & 2.42 & 2.82 \\
\hline Same day as Akidienu & 8.2 & 8.0 & 31.9 & 23.4 & 2.58 & 1.75 & 2.17 \\
\hline 2 weeks after Akidienu & 4.7 & 5.2 & 26.2 & 19.6 & 1.17 & 0.92 & 1.05 \\
\hline 4 weeks after Akidienu & 2.4 & 4.8 & 30.6 & 16.7 & 0.75 & 0.92 & 0.84 \\
\hline 4 weeks before IT97K- & 10.7 & 14.3 & 38.6 & 22.9 & 4.08 & 3.32 & 3.70 \\
\hline 2 weeks before IT97K- & 11.5 & 16.8 & 32.4 & 25.9 & 3.75 & 4.45 & 4.10 \\
\hline Same day as IT97K- & 6.8 & 10.6 & 35.4 & 22.7 & 2.38 & 2.32 & 2.35 \\
\hline 2 weeks after IT97K- & 4.3 & 6.5 & 27.4 & 16.5 & 1.13 & 1.00 & 1.07 \\
\hline 4 weeks after IT97K- & 4.3 & 5.5 & 28.2 & 26.4 & 1.21 & 1.62 & 1.42 \\
\hline Sole cocoyam & 14.0 & 16.6 & 30.7 & 24.3 & 4.42 & 3.83 & 4.13 \\
\hline LSD 0.05 & 3.7 & 4.7 & NS & NS & 1.41 & 0.90 & 1.42 \\
\hline
\end{tabular}

$\mathrm{NS}=$ not significant; coco $=$ cocoyam; $\mathrm{NC}=$ number of corms; $\mathrm{WC}=$ weight of corms; $\mathrm{CY}=$ corm yield;

IT97K- = IT97K-499-35

TABLE 6

Effect of time of introducing cowpea on cowpea's plant height (cm), root dry matter (g/plant) and shoot dry matter (g/plant) at 1 MAP in 2012 and 2013 cropping seasons

\begin{tabular}{lllllll}
\hline & \multicolumn{3}{l}{ Plant height } & \multicolumn{2}{l}{ Root dry matter } & \multicolumn{2}{l}{ Shoot dry matter } \\
\hline Time of introducing cowpea & 2012 & 2013 & 2012 & 2013 & 2012 & 2013 \\
Akidienu 4 WB cocoyam & 23.3 & 34.5 & 0.42 & 0.64 & 2.32 & 3.85 \\
Akidienu 2 WB cocoyam & 25.7 & 47.6 & 0.38 & 0.55 & 3.06 & 4.70 \\
Akidienu SD as cocoyam & 31.7 & 41.0 & 0.50 & 0.59 & 2.93 & 4.12 \\
Akidienu 2 WA cocoyam & 27.8 & 45.8 & 0.33 & 0.48 & 2.28 & 3.51 \\
Akidienu 4 WA cocoyam & 21.9 & 19.2 & 0.40 & 0.46 & 2.05 & 2.99 \\
Sole Akidienu & 25.5 & 39.6 & 0.38 & 0.63 & 2.45 & 4.21 \\
IT97K- 4 WB cocoyam & 16.3 & 18.6 & 0.47 & 0.63 & 2.30 & 3.99 \\
IT97K- 2 WB cocoyam & 14.8 & 17.8 & 0.54 & 0.61 & 2.62 & 3.55 \\
IT97K- $\quad$ SD as cocoyam & 16.1 & 19.9 & 0.64 & 0.75 & 3.70 & 5.21 \\
IT97K- 2 WA cocoyam & 15.1 & 16.9 & 0.40 & 0.56 & 2.40 & 3.23 \\
IT97K- 4 WA cocoyam & 15.6 & 16.3 & 0.27 & 0.48 & 1.83 & 2.99 \\
Sole IT97K- & 15.2 & 20.0 & 0.54 & 0.74 & 2.81 & 3.88 \\
LSD 0.05 & NS & 22.6 & NS & NS & NS & NS \\
& & & & & & \\
\hline
\end{tabular}

$\mathrm{NS}=$ not significant; $\mathrm{WB}=$ weeks before, $\mathrm{WA}=$ weeks after, $\mathrm{SD}=$ same day, IT97K- = IT97K-499-35 
TABLE 7

Effect of time of introducing cowpea on pod yield and pod yield components in 2012 and 2013 cropping seasons

\begin{tabular}{|c|c|c|c|c|c|c|c|}
\hline \multirow[b]{2}{*}{ Time of introducing cowpea } & \multicolumn{2}{|c|}{ NP per plant } & \multicolumn{2}{|c|}{$P W$ g/pod } & \multicolumn{3}{|c|}{$P Y t h a^{-1}$} \\
\hline & 2012 & 2013 & 2012 & 2013 & 2012 & 2013 & $\overline{\text { Mean }}$ \\
\hline Akidienu 4 WB cocoyam & 14.8 & 11.4 & 6.74 & 12.98 & 3.98 & 6.13 & 5.06 \\
\hline Akidienu 2 WB cocoyam & 15.7 & 13.2 & 8.00 & 12.09 & 5.14 & 6.52 & 5.83 \\
\hline Akidienu SD as cocoyam & 16.1 & 10.2 & 9.94 & 14.58 & 6.81 & 5.56 & 6.19 \\
\hline Akidienu 2 WA cocoyam & 5.7 & 4.6 & 6.53 & 11.93 & 1.50 & 2.10 & 1.80 \\
\hline Akidienu 4 WA cocoyam & 3.9 & 3.8 & 6.45 & 11.04 & 1.02 & 1.63 & 1.33 \\
\hline Sole Akidienu & 11.6 & 11.4 & 8.07 & 13.22 & 3.65 & 6.23 & 4.94 \\
\hline IT97K- $\quad 4$ WB cocoyam & 14.3 & 27.6 & 9.72 & 16.47 & 5.66 & 18.11 & 11.89 \\
\hline IT97K- $\quad 2$ WB cocoyam & 16.3 & 27.0 & 12.61 & 17.70 & 8.26 & 18.30 & 13.28 \\
\hline SD as cocoyam & 15.0 & 32.2 & 9.57 & 16.46 & 5.71 & 21.18 & 13.45 \\
\hline IT97K- 2 WA cocoyam & 14.0 & 15.0 & 9.33 & 12.51 & 5.44 & 7.09 & 6.27 \\
\hline IT97K- $\quad 4$ WA cocoyam & 8.0 & 10.3 & 8.68 & 11.51 & 2.78 & 4.74 & 3.76 \\
\hline Sole IT97K- & 13.8 & 24.3 & 8.04 & 15.25 & 3.75 & 14.61 & 9.18 \\
\hline LSD 0.05 & 5.9 & 8.6 & 3.14 & NS & 3.02 & 5.45 & 3.47 \\
\hline
\end{tabular}

$\mathrm{NS}=$ not significant; $\mathrm{WB}=$ weeks before, $\mathrm{WA}=$ weeks after, $\mathrm{SD}=$ same day, IT97K- = IT97K-499-35, NP = number of pods, $\mathrm{PW}=$ pod weight, $\mathrm{PY}=$ pod yield

TABLE 8

Effect of time of introducing cowpea on seed yield and seed yield components in 2012 and 2013 cropping seasons

\begin{tabular}{|c|c|c|c|c|c|c|}
\hline \multirow[b]{2}{*}{ Time of introducing cowpea } & \multicolumn{2}{|c|}{ No. of seeds pod ${ }^{-1}$} & \multicolumn{2}{|c|}{100 seed weight $(g)$} & \multicolumn{2}{|c|}{ Seed yield $\mathrm{kg} \mathrm{ha}^{-1}$} \\
\hline & 2012 & 2013 & 2012 & 2013 & 2012 & 2013 \\
\hline Akidienu 4 WB cocoyam & 17.7 & 19.8 & 9.60 & 12.80 & 134.7 & 117.0 \\
\hline Akidienu 2 WB cocoyam & 18.2 & 20.0 & 13.52 & 13.17 & 156.2 & 138.4 \\
\hline Akidienu $\mathrm{SD}$ as cocoyam & 19.0 & 19.6 & 13.68 & 13.50 & 171.8 & 106.3 \\
\hline Akidienu 2 WA cocoyam & 16.8 & 18.8 & 10.58 & 11.08 & 40.3 & 39.6 \\
\hline Akidienu 4 WA cocoyam & 16.3 & 18.1 & 10.76 & 11.34 & 26.6 & 31.0 \\
\hline Sole Akidienu & 17.8 & 20.1 & 12.12 & 12.85 & 111.5 & 107.2 \\
\hline 4 WB cocoyam & 11.8 & 15.1 & 18.47 & 22.46 & 122.2 & 373.7 \\
\hline 2 WB cocoyam & 12.8 & 14.3 & 13.50 & 17.51 & 114.0 & 269.1 \\
\hline $\mathrm{SD}$ as cocoyam & 13.5 & 14.6 & 15.00 & 18.05 & 122.3 & 337.2 \\
\hline IT97K- 2 WA cocoyam & 12.8 & 13.8 & 16.23 & 19.65 & 116.7 & 161.4 \\
\hline IT97K- $\quad 4$ WA cocoyam & 12.5 & 13.1 & 17.00 & 20.38 & 68.3 & 109.2 \\
\hline Sole IT97K- & 12.3 & 13.6 & 14.07 & 19.57 & 96.2 & 268.0 \\
\hline$\underline{\text { LSD } 0.05}$ & 1.9 & 1.4 & 4.45 & 4.33 & 72.7 & $113.5 \mathrm{NS}=$ \\
\hline
\end{tabular}

not significant; WB = weeks before, WA = weeks after, $\mathrm{SD}=$ same day, IT97K- = IT97K-499-35 
Time of introducing component crop influences...

TABLE 9

Partial and total land equivalent ratio (LER) of cocoyam/cowpea intercrop in 2012 and 2013 cropping seasons

\begin{tabular}{|c|c|c|c|c|c|c|c|}
\hline \multirow{3}{*}{ Time of introduction } & & & & \multicolumn{2}{|c|}{ Partial LER } & \multicolumn{2}{|c|}{ Total LER } \\
\hline & \multirow{2}{*}{\multicolumn{2}{|c|}{$\frac{\text { Coco cowpea }}{2012}$}} & \multirow{2}{*}{\multicolumn{2}{|c|}{$\begin{array}{c}\text { Coco cowpea } \\
2013 \\
\end{array}$}} & \multirow{3}{*}{$\begin{array}{l}2012 \\
1.00\end{array}$} & \multirow{3}{*}{$\begin{array}{c}2013 \\
1.00\end{array}$} & \multirow{3}{*}{$\frac{\text { Mean }}{1.00}$} \\
\hline & & & & & & & \\
\hline Sole & 1.00 & 1.00 & 1.00 & 1.00 & & & \\
\hline Cocoyam 4 WB Akidienu & 0.93 & 0.29 & 0.81 & 0.32 & 1.22 & 1.13 & 1.18 \\
\hline Cocoyam 2 WB Akidienu & 0.77 & 0.43 & 0.78 & 0.39 & 1.20 & 1.17 & 1.19 \\
\hline Cocoyam SD as Akidienu & 0.66 & 1.92 & 0.50 & 1.14 & 2.58 & 1.64 & 2.09 \\
\hline Cocoyam 2 WA Akidienu & 0.27 & 1.70 & 0.28 & 1.32 & 1.97 & 1.60 & 1.79 \\
\hline Cocoyam 4 WA Akidienu & 0.17 & 1.24 & 0.27 & 1.23 & 1.41 & 1.50 & 1.46 \\
\hline Cocoyam 4 WB IT97K- & 0.95 & 0.77 & 1.00 & 0.33 & 1.72 & 1.33 & 1.53 \\
\hline Cocoyam 2 WB IT97K- & 0.91 & 1.54 & 1.35 & 0.49 & 2.45 & 1.84 & 2.15 \\
\hline Cocoyam SD as IT97K- & 0.58 & 1.55 & 0.66 & 1.49 & 2.13 & 2.15 & 2.14 \\
\hline Cocoyam 2 WA IT97K- & 0.27 & 0.28 & 0.32 & 1.32 & 2.55 & 1.64 & 2.10 \\
\hline Cocoyam 4 WA IT97K- & 0.28 & 1.58 & 0.57 & 1.23 & 1.86 & 1.80 & 1.83 \\
\hline
\end{tabular}

NS = not significant; WB = weeks before, WA = weeks after, $\mathrm{SD}=$ same day, IT97K- = IT97K-499-35

TABLE 10

Land equivalent coefficient (LEC) and area $x$ time equivalent ratio (ATER) of cocoyam/cowpea intercrop in 2012 and 2013 cropping seasons

\begin{tabular}{|c|c|c|c|c|c|c|}
\hline \multirow{2}{*}{ Time of introducing cowpea } & \multirow[b]{2}{*}{2012} & \multirow{2}{*}{$\begin{array}{ll}L E C \\
2013\end{array}$} & \multirow[b]{2}{*}{ Mean } & \multirow[b]{2}{*}{2012} & \multirow{2}{*}{$\begin{array}{l}\text { ATER } \\
2013\end{array}$} & \multirow[b]{2}{*}{ Mean } \\
\hline & & & & & & \\
\hline Sole cocoyam & 1.00 & 1.00 & 1.00 & NA & NA & NA \\
\hline Sole Akidienu & 1.00 & 1.00 & 1.00 & NA & NA & NA \\
\hline Sole IT97K-499-35 & 1.00 & 1.00 & 1.00 & NA & NA & NA \\
\hline Cocoyam 4 WB Akidienu & 0.27 & 0.26 & 0.26 & 1.05 & 0.94 & 1.00 \\
\hline Cocoyam 2 WB Akidienu & 0.33 & 0.30 & 0.32 & 0.95 & 0.95 & 0.95 \\
\hline Cocoyam SD as Akidienu & 1.27 & 0.57 & 0.92 & 1.48 & 0.99 & 1.24 \\
\hline Cocoyam 2 WA Akidienu & 0.46 & 0.37 & 0.42 & 1.00 & 0.85 & 0.93 \\
\hline Cocoyam 4 WA Akidienu & 0.21 & 0.33 & 0.27 & 0.70 & 0.80 & 0.75 \\
\hline Cocoyam 4 WB IT97K- & 0.73 & 0.33 & 0.53 & 1.28 & 1.14 & 1.21 \\
\hline Cocoyam 2 WB IT97K- & 1.40 & 0.66 & 1.03 & 1.57 & 1.56 & 1.57 \\
\hline Cocoyam SD as IT97K- & 0.90 & 0.98 & 0.94 & 1.24 & 1.30 & 1.27 \\
\hline Cocoyam 2 WA IT97K- & 0.62 & 0.42 & 0.52 & 1.25 & 0.89 & 1.07 \\
\hline Cocoyam 4 WA IT97K- & 0.44 & 0.70 & 0.57 & 0.96 & 1.10 & 1.03 \\
\hline
\end{tabular}

$\mathrm{NA}=$ not applicable; $\mathrm{WB}=$ weeks before, $\mathrm{WA}=$ weeks after, $\mathrm{SD}=$ same day, IT97K- = IT97K-499-35 